\title{
Análise construcional das perífrases cursivas de gerúndio: um estudo comparativo do galego e do português
}

\section{A constructional analysis of gerund cursive periphrastic structures in Galician and Portuguese: a comparative study}

\author{
Quezia dos S. Lopes Oliveira \\ Universidade Federal do Rio de Janeiro (Brasil) \\ queziaslopes@gmail.com \\ ORCID: https://orcid.org/0000-0001-6986-9116
}

Enviado: 22/03/2021

Aceptado: 15/06/2021

\section{Resumo}

Este artigo se propóe a analisar, num dado recorte temporal (Séculos XX e XXI), as construçóes perifrásticas de gerúndio marcadoras do aspecto imperfectivo cursivo no galego, especificamente as formadas pelos auxiliares estar e ficar. O objetivo deste estudo é comparar os resultados iniciais encontrados para o comportamento dessas construçóes no galego com os já atestados para o português quanto ao mesmo fenômeno. $\mathrm{O}$ trabalho segue a orientação dos modelos baseados no uso e da abordagem de construcionalizaçáo e mudança construcional de Traugott $\&$ Trousdale (2013). A análise é comparativa. O método correspondeu à coleta dos dados em dois bancos de textos do galego contemporâneo e à análise desses dados quanto a fatores analíticos que caracterizassem o contexto de ocorrência dessas construçôes, a saber: tipo semântico do verbo principal (V2), animacidade do sujeito e presença de material interveniente entre os elementos da perífrase (Verbo auxiliar (V1) e principal (V2)). Os resultados apontam para um perfil de uso das construçóes [estar $+\mathrm{X}-n$ do $]_{\text {cursivo }}$ e [ficar $+\mathrm{X}-n d o]_{\text {cursivo }}$ muito semelhante nas duas línguas em análise, ratificando, portanto, a hipótese sugerida para o fenômeno no português em Oliveira (2018) de que a construção formada por estar está mais avançada no processo de mudança construcional do que a constituída por ficar. Além disso, desse estudo comparativo, foi possível também traçar algumas particularidades desses dois idiomas no que se refere ao estudo em questão.

\section{Palabras-chave}

Relação galego-português; Construçôes perifrásticas de gerúndio; Mudanças construcionais.

\section{Sumário}

1. Introdução. 2. Abordagem teórica. 3. Metodologia. 4. Categorias de análise. 5. Resultados. 5.1. Tipo semântico de V2. 5.2. Animacidade do sujeito. 5.3. Material interveniente. 6. Convergências e divergências entre o galego e o português no fenômeno em análise. 7. Considerações finais.

\section{Abstract}

This article intends to analyze, in a given time frame (20th and 21st centuries), the periphrastic constructions of gerund that are markers of the imperfective cursive aspect in Galician, specifically those formed by the auxiliaries estar and ficar. The aim of this study is to compare the initial results found for the behavior of these constructions in Galician with those already attested in Portuguese regarding the same phenomenon. The work follows the orientation of the usage-based models and of the constructionalization and constructional change approach of Traugott $\&$ Trousdale (2013). The analysis is comparative. The method used was the collection of data in two contemporary Galician text banks and the analysis of these data regarding analytical factors that characterized the context of occurrence of these constructions, namely: semantic type of the main verb (V2), subject animacy and presence of intervening material between the elements of the periphrase (Auxiliary (V1) and main verb(V2)). The results point to a very similar profile of use of the constructions [estar $+\mathrm{X}-n d o$ ] cursive and $[$ ficar $+\mathrm{X}-n d o]$ cursive in the two languages under analysis, thus confirming the hypothesis suggested for the phenomenon in Portuguese in Oliveira (2018) that the construction formed by estar is more advanced in the process of constructional change than the construction formed by ficar. In addition, from this comparative study, it was also possible to trace some particularities of these two languages related to the study developed.

\section{Keywords}

Galician-Portuguese relationship; Periphrastic gerund constructions; Constructional changes.

\section{Summary}

1. Introduction. 2. Theoretical approach. 3. Methodology. 4. Categories of analysis. 5. Results. 5.1. Semantic type of V2. 5.2. Subject's animation. 5.3. Intervening material. 6. Convergences and divergences between Galician and Portuguese in the phenomenon under analysis. 7. Final considerations. 


\section{Introdução}

$\mathrm{O}$

PRESENTE artigo tem por finalidade comparar o comportamento atual do galego e do português do Brasil ${ }^{1}$ quanto às construçôes estar + gerúndio e ficar + gerúndio, representadas daqui para frente como $[e s t a r+\mathrm{X}-n d o]_{\text {cursivo }}$ e $[\text { ficar }+\mathrm{X}-n d o]_{\text {cursivo }}$, na expressão do aspecto imperfectivo cursivo ("Estou lendo"; "Fico esperando"), na tentativa de mapear o comportamento dessas construçóes no galego e estabelecer suas aproximaçóes e distanciamentos em relação ao $\mathrm{PB}$. A proposta é procurar traçar um possível padrão de emprego dessas construçôes nessas línguas, dada a relação de herança que existe entre elas e o fato de os primeiros usos dessas construçóes, identificadas em amostras de estudo precedente (Oliveira 2018), datarem de um período anterior à separação dessas duas línguas, o que pode apontar para uma equivalência de comportamento deste fenômeno nesses dois idiomas atualmente.

Este artigo é fruto de uma pesquisa maior realizada em Oliveira (2018), que investigou, diacronicamente, essas construçôes no português e observou nesta língua que a construção composta por estar na forma auxiliar se mostra num estágio mais avançado de mudança construcional que a construçáo com ficar, apresentando um contexto de ocorrência mais rico e variado que esta última. $\mathrm{O}$ emprego mais amplo daquela construção diz respeito, sobretudo, à seleção do sujeito da perífrase, à escolha do tipo semântico do seu V2, à redução fonética particular e mais recorrente do seu V1, à manutenção do aspecto cursivo em situaçóes mais variadas, à marcação mais neutra do aspecto cursivo comparada às demais construçóes do grupo, e à utilização da construção em ambientes inovadores, como nas construções de gerundismo ${ }^{2}$. Porém, por não ser o foco desta análise, o debate realizado aqui não se estenderá por essas questóes.

Esse trabalho observou que, no português, as construçôes perifrásticas marcadoras de aspecto cursivo restringem-se a poucas possibilidades de preenchimento da posição de V1/auxiliar ${ }^{3}$. Estudos indicam, porém, que essas possibilidades náo surgi-

1. Doravante PB.

2. Termo adotado pela gramática normativa para classificar construçóes de gerúndio formadas pela estrutura [ir + estar + gerúndio], como em: "Vou estar enviando". Conferir também Torres (2009).

3. Para Castilho (1968: 60), as perífrases que exprimem duração correspondem às de: "ficar, continuar, estar, ir, vir, seguir, permanecer + a + infinitivo ou gerúndio, neste caso sem a preposição". Em outro momento do texto, o autor enumera as perífrases cursivas identificadas em seu trabalho. São elas: "prosseguir, estar, ir, vir, seguir e permanecer". (Castilho 1968: 111). Em Travaglia (2015: 294-295) também é possível identificar essas mesmas perífrases para marcação desse aspecto. É válido ressaltar, porém, que há divergências na literatura quanto à nomenclatura aspectual. Lehmann (2008: 8-9, 13), por exemplo, ao tratar da auxiliarização de ficar, classifica as perífrases desse verbo como progressivas, que, pelo que se observa de sua análise, corresponde ao que os autores chamam de durativo/ cursivo; além de haver estudiosos, como Volpato \& Pereira (1997), que também adotam o termo progressivo para construçóes deste tipo. 
ram ao mesmo tempo, foram sendo permitidas na língua ao longo de sua história, a partir do alargamento do esquema construcional deste tipo, o que possibilitou, por exemplo, o recrutamento de ficar sob influência das construçóes já formadas por estar, como mostra Lehmann (2008: 9). Dado esse passo inicial procedido por estar, a hipótese levantada foi a de que este tenha avançado mais no seu processo de mudança e influenciado o comportamento daquele nesse novo contexto, o que foi comprovado para o português pela confluência de outras evidências, como as já sinalizadas.

Essa pesquisa também lançou uma discussão inicial sobre este fenômeno no galego com a finalidade de ratificar os resultados atestados para o português, e é sobre esta discussão levantada que este artigo se debruça, na tentativa de trazer luz a essas questôes e ampliar esse debate, que, apesar de ainda estar em curso, permite fazer certas sinalizaçóes do comportamento das construçóes aqui em análise nos dois idiomas.

O objetivo neste momento não é esgotar a análise do tema, que demanda muitas questôes, mas ainda é pouco explorado na literatura, mas trazer, de modo sucinto, os resultados mais expressivos dessa comparação, ajudando, com isso, a promover este debate na comunidade científica. Vale destacar que náo se procederá a uma análise direta do português aqui, mas se referirá aos resultados já observados para esta língua nesse estudo anteriormente citado. $\mathrm{O}$ foco deste artigo recairá, portanto, nos dados do galego. É esperado verificar para o galego um processo semelhante ao do $\mathrm{PB}$, o de maior expansão da mudança das construções perifrásticas com estar.

Convém lembrar também que não há trabalhos prévios na literatura dessas duas línguas dentro desse recorte temático e teórico-metodológico. Porém, estudos mais gerais sobre o tema nessas línguas podem contribuir para a caracterização inicial do fenômeno. Dentre eles, embasarão mais diretamente este trabalho os de Castilho (1968) e Travaglia (2015), para o português, e os de Rojo (1974) e Freixeiro Mato (2002), bem como as gramáticas de Álvarez e Xove (2002) e Freixeiro Mato (2006), para o galego.

Segundo Freixeiro Mato (2002: 271, 274), as perífrases verbais do galego podem ser classificadas em temporais, modais e aspectuais, sendo estas do tipo incoativas, imperfectivas, perfectivas, reiterativas e terminativas. No caso das imperfectivas, foco deste trabalho, podem ser realizadas na forma auxiliada por um gerúndio ou pelo chamado infinitivo gerundial ( $a+$ infinitivo), ambas de valor durativo, segundo Rojo (1974: 102). Quanto aos auxiliares, essas perífrases utilizam os verbos estar, andar, ir, vir, levar, continuar e seguir, além do ser, que, diferentemente dos demais, ocorre apenas com a forma $a+$ infinitivo (Freixeiro Mato 2002: 275). Neste artigo, consideramos também as formadas pelo verbo estativo ficar, que, pela interpretação semântica dos dados, apresenta um comportamento muito semelhante ao das perífrases com estar, o que já foi sinalizado em outros estudos para o português (Lehmann 2008; Oliveira 2018; Castilho 1968: 60).

Rojo (1974: 68) e Freixeiro Mato (2002: 270) conceituam perífrases verbais como um conjunto de base verbal com unidade sintática e semântica correspondente 
a um sistema paralelo de conjugação. Rojo (1974: 68) também acrescenta que elas expressam matizações verbais com respeito a tempo, aspecto, modalização, voz, para além da expressão básica já realizada pela conjugação de uma forma verbal simples. Para o autor, as perífrases constituem um tipo de complexo verbal, o de significação conjunta/indissociável, ao lado de outros que se caracterizam pela significação disjunta, isto é, quando suas partes componentes somam seus significados individuais para significação total do conjunto.

Destaca ainda uma particularidade da língua galega quanto a essa questão: "Refiriéndonos concretamente al gallego, la escasez de formas conjugacionales da todavía mayor importancia a su sistema perifrástico.” (Rojo 1974: 69). As perífrases funcionam, então, segundo o autor, como um recurso morfológico altamente produtivo nesta língua, sobretudo as aspectuais, visto que essa noção não se encontra bem atendida na conjugação em sentido estrito (Rojo 1974:101). Isso as torna formas marcadas em relação às não perifrásticas, com indicação mais expressiva da duração da ação. Essa é uma singularidade que tem sido apontada por vários autores com relação às línguas românicas em geral, conforme aponta Barroso (1994: 79), que entende esse processo como algo além de um mero recurso expressivo:

Por isso, para quem, eventualmente, pense que as construçóes em causa não passam de um processo enfático das respectivas formas simples, objectamos dizendo que tal posição é absolutamente contestável. Porque, se as línguas românicas (e de modo particular o português) recorreram e constantemente recorrem a esses processos, não foi/é por um mero prazer lúdico (que, por vezes, se pode manifestar nos diversos actos de fala), mas por uma forte necessidade expressiva: é que as formas simples não eram já mais suficientes para expressarem toda uma série de nuances decorrentes do processo verbal. (Barroso 1994: 87)

Como visto até aqui, uma primeira especificidade do galego em comparação com o PB é o uso significativo do "infinitivo gerundial", sobretudo dialetalmente (Freixeiro Mato 2006: 407), que funciona como variante da perífrase de gerúndio na marcação aspectual imperfectiva, como apontam também Maurer (1968), Rojo (1974:102) e Álvarez \& Xove (2002: 409). O que permite que ambas as construçóes expressem o valor aspectual é, na visão de Rojo (1974: 102), o fato de o gerúndio indicar o não-término do processo, e o infinitivo não fazer referência a ele, correspondendo, portanto, ao ponto neutro.

De acordo com Freixeiro Mato (2006: 418), o emprego dessa variante no galego surgiu dialetalmente em meados do Século XIX e se consolidou no Século XX, estando condicionado hoje, principalmente, a fatores estilísticos e de distribuição geográfica. Ademais, o autor aponta que este uso, apesar de significativo, sobretudo dialetalmente, não é tão recorrente quanto na variante portuguesa, que o faz majo- 
ritariamente em suas diversas distribuiçôes geográficas. Posto isso, parece haver, portanto, entre o galego, português europeu (PE) e o PB um contínuo na distribuição das perífrases de gerúndio e de infinitivo. De um lado, observa-se a predominância das construçóes de infinitivo gerundial no português europeu, de outro, as de gerúndio no PB, estando o galego entre esses dois polos.

Canto ao uso do xerundio ou do infinitivo xerundial, o galego está máis próximo da norma brasileira do que da portuguesa, se ben cada vez máis o uso do infinitivo preposicionado está a gañar prestixio na lingua culta. Este último acentúa máis a imperfectividade da acción, como apontan Vásquez Cuesta/ Mendes da Luz (1971, II: 88) e Rojo (1974: 105, 115), quen, tras coincidir coas autoras da gramatica portuguesa en que estar $a+$ infinitivo designa unha acción máis momentánea do que o presente de Indicativo e que ese é tamén en galego o valor máis frecuente de tal construción, afirma que con $a+$ infinitivo "puede hablarse de un recargamiento de la imperfectividad frente a la más general construcción com gerundio", sendo para el este o motivo de que apareza con tanta frecuencia na literatura, xuntamente co feito de esta construción non existir en castelán. (Freixeiro Mato 2002: 275)

Feitas essas consideraçôes iniciais, este artigo apresentará na sequência (\$2) uma breve revisão do quadro teórico que o subsidia, além de elucidar alguns conceitos básicos envolvendo a terminologia empregada na análise das construçôes. Em seguida (\$3), comentará os procedimentos metodológicos adotados e as informaçóes gerais sobre a amostra examinada. Em (\$4), discutirá as categorias de análise e, na sequência (\$5), fará uma análise do quadro geral do galego quanto ao fenômeno investigado. Já na seção (\$6) discutirá as semelhanças e diferenças entre essa língua e o PB com respeito ao recorte temático-temporal aqui procedido. Por fim $(\$ 7)$, passará às consideraçôes finais deste trabalho.

\section{A abordagem teórica}

Este trabalho se insere no quadro teórico dos modelos funcionais baseados no uso, assume uma visão de língua como uma habilidade cognitiva geral, e a de gramática como uma grande rede de construçóes interconectadas. Orienta-se pela consideração de que o uso motiva e modifica a estrutura linguística, sendo, por isso, de fundamental importância observar a construção em seu contexto mais amplo de emprego. Também considera, sob a ótica da construcionalização e mudança construcional, de Traugott \& Trousdale (2013), que a construção é um pareamento de forma e significado, em que forma diz respeito aos aspectos morfossintáticos do signo, e significado, às informaçóes semântico-discursivo-pragmáticas codificadas por ele. Secundariamente 
recorre também a algumas consideraçôes do paradigma da gramaticalização, visto o diálogo dessa abordagem com a adotada neste trabalho e o auxílio que pode conferir para uma análise mais ampla do fenômeno.

A metodologia aqui empregada, como se verá mais adiante $(\$ 3)$, se assenta nos trabalhos realizados para o estudo da mudança linguística, sob a ótica da Linguística centrada no uso, especificamente naqueles tratados pela teoria da construcionalização e mudança construcional, na perspectiva de Traugot $\&$ Trousdale (2013).

Dentro do marco teórico central deste trabalho, construcionalização é entendida como o processo de criação de um "nó" (construção) na rede construcional a partir de um novo pareamento de uma forma e um significado. Já a mudança construcional, como o processo de alteraçáo em uma dessas duas faces (forma ou significado), podendo culminar, no caso de alteração nas duas dimensóes, em uma possível nova construcionalizaçáo. Tais mudanças podem se dar antes e depois de cada construcionalização. Seriam, portanto, o estágio predecessor, e necessário, de cada nova construcionalização.

O estudo de uma dada construção, a partir dessa perspectiva, visa a analisar as alteraçôes processadas nas duas faces de um item linguístico (forma e significado) até a constituição de um novo nó (novo pareamento forma-significado) na rede linguística de uma comunidade de fala (construcionalização) e as alteraçóes ocorridas nessas construçôes em uma de suas dimensões após a sua formação (mudança construcional). Dessa forma, avalia tanto a construcionalização quanto as mudanças construcionais de uma dada construção da língua. A verificação desses fenômenos é feita, basicamente, a partir do exame das alteraçóes na esquematicidade, produtividade e composicionalidade de uma construção na rede.

Antes de passar à explicitaçáo desses conceitos, porém, cabe salientar que, apesar de o nome "mudança construcional" remeter, numa primeira impressão, ao resultado de um processo, refere-se, antes, nesta teoria, ao percurso/andamento desse processo, às fases anteriores e posteriores à criação do novo nó. Trata do caminho da transformação em si, e não da substituição já processada.

Sobre os conceitos anteriormente aludidos, cumpre dizer que a esquematicidade é entendida aqui como uma propriedade de categorização que envolve abstração num nível vertical. Ela permite avaliar o quanto é possível fazer generalizaçóes acima de um mesmo eixo relacional. Desse modo, é possível organizar as construçóes, neste quadro teórico, numa rede distribuída em três níveis básicos: esquema (nível mais abstrato; Ex.: aspecto cursivo), subesquema (nível intermediário; Ex.: perífrases de gerúndio, perífrases de infinitivo etc.) e microconstrução (nível mais básico, que abarca diferentes types. Ex.: $[\text { estar }+\mathrm{X}-n d o]_{\mathrm{CURSIVO}} ;[\text { ficar }+\mathrm{X}-n d o]_{\mathrm{CURSIVO}} ;[$ estar $+a+$ $\mathrm{X}-r]_{\text {CURSIVO }}$ etc.).

O conceito de produtividade para Traugott \& Trousdale (2013: 17-18) refere-se à extensibilidade de um esquema em termos de alargamento de uma construção, licenciando novas construçôes menos esquemáticas, bem como de suas restriçốes. É o 
que acontece no português no recrutamento de novos auxiliares para a formação das perifrásticas de gerúndio, como ocorreu com ficar seguindo o caminho já procedido por estar, como já apontado anteriormente em referência a Lehmann (2008: 9). O conceito de produtividade também costuma estar associado, na literatura, às frequências token (frequência de ocorrência de uma dada unidade/construção ao longo da amostra; de valor quantitativo) e type (frequência de tipo, que corresponde à diversidade de entradas de dicionário de um padrão particular; de valor qualitativo) (Bybee 2003; 2010: 67, 95-96) e ao aumento da gama colocacional nos slots que compóem um esquema de uma construção (Himmelman 2004: 32-33). Assim, uma construção seria mais produtiva se aumentasse sua frequência e contexto de uso e se se abrisse a novas possibilidades de preenchimento de suas lacunas, ou seja, se expandisse suas frequências de ocorrência e de tipo.

A composicionalidade, por sua vez, é entendida em termos de congruência ou falta de correspondência entre aspectos da forma e do significado, levando em conta aspectos semânticos (o significado das partes e do todo) e propriedades combinatórias do componente sintático: "o significado de uma expressão é uma função do significado de suas partes e da maneira como elas estão sintaticamente combinadas" (Partee 1984: 281, apud Traugott \& Trousdale 2013: 19- tradução nossa ${ }^{4}$ ). Assim sendo, uma construção é entendida como mais composicional quando se pode computar mais claramente a soma dos valores individuais de suas partes para o cômputo do sentido final do seu todo. Por outro lado, seria menos composicional se se identificam faltas de correspondências semântico-sintáticas entre o significado das partes e o significado do todo. Também pode ser pensada em termos de perda de analisabilidade, que, para Traugott \& Trousdale (2013: 20), funciona como um subtipo da composicionalidades.

Analyzability, unlike compositionality, is not primarily associated with the imputed match of the meaning of whole across the meaning of the parts of a composite expression. Rather, it is concerned with the extent to which speakers recognize, and treat distinctly, those component parts. (Traugott \& Trousdale 2013: 20) ${ }^{6}$

A interpretação que se faz desses conceitos para a averiguação do processo da mudança é a de que o avanço da mudança está associado ao aumento de esquematici-

4. No original: "the meaning of an expression is a function of the meanings of its parts and the way they are syntactically combined"'. (Partee 1984: 281, apud Traugott \& Trousdale 2013: 19)

5. Cf. Bybee $(2003,2010)$.

6. "A analisabilidade, ao contrário da composicionalidade, não está primariamente associada ao computo do significado do todo através do significado das partes de uma expressão composta. Em vez disso, avalia com que extensão o falante reconhece e trata distintamente cada parte componente da construção" (Traugott \& Trousdale 2013: 20- [Traduçáo nossa]. 
dade e de produtividade da construção e à consequente diminuição de sua composicionalidade (Traugott \& Trousdale 2013: 112-113). Em outros termos, a construção em avanço de mudança se torna mais frequente, amplia seu escopo de uso e perde certas restrições. Isso é percebido pela ocorrência/seleção de elementos mais variados para preencher seus slots, bem como pelo abarcamento de novas construçóes na rede. Também é verificado quando os constituintes da construção deixam cada vez mais de ser enxergados como partes de um arranjo de elementos combinados, para serem entendidos em seu todo, como um bloco único.

No que diz respeito ao conceito de perífrase verbal, cumpre apontar, em linhas gerais, a abordagem adotada neste trabalho. Aqui a perífrase é entendida como a combinação de um verbo auxiliar (V1) com um verbo principal (V2), em uma de suas formas nominais (infinitivo, gerúndio ou particípio) (Coelho 2006: 69; Travaglia 2015: 181), em que o verbo auxiliar é responsável pela expressão das informaçôes gramaticais (tempo, pessoa, número, modo) e o principal pela semântica da ação verbal, formando um bloco integrado de forma e função, ou seja, "presentan unidade formal e teñen unha significación conxunta", Álvarez \& Xove (2002: 404).

Quanto à avaliação dos auxiliares e, em consequência, das perífrases verdadeiras, não é ponto consensual entre os estudiosos, havendo diversificadas propostas ${ }^{7} \mathrm{de}$ testes de ordem sintático-semânticos para averiguação da integração do complexo verbal e assunção dos casos perifrásticos. Em vista disso, são observados na literatura, de um lado, grupos de perífrases extremamente abertos e, de outro, demasiadamente fechados (Rojo 1974: 28). Dentre os critérios para esta delimitação, estão os testes de apagamento/omissão de V2 (por meio da estratégia de interrogação, por exemplo), substituição pronominal de V2 (comutação), passivização, observação de restriçôes na seleção de argumentos ou no compartilhamento de sujeito por V1 e V2, esvaziamento semântico do auxiliar, constatação de casos ambíguos e outros, como apontam diferentes autores, a exemplo de Rojo (1974: 28), Olbertz (1998: 166) e Freixeiro Mato (2002).

No entanto, dentro da perspectiva teórica adotada neste trabalho, que toma a perífrase verbal como uma construção perifrástica ${ }^{8}$, são adotados parâmetros de análise próprios para verificação de constituição de uma construção, quais sejam: níveis de esquematicidade, composicionalidade e produtividade. No caso específico da verificação da unidade perifrástica da construção, a composicionalidade se mostra um fator determinante, correspondente mais diretamente aos testes de validação das perífrases referenciados anteriormente, que também são assumidos neste trabalho, mas como recursos auxiliares à análise. Mais adiante detalham-se alguns procedimentos

7. Dentre esses trabalhos, destacam-se, no português, as propostas de Lobato (1975), Longo (1990), Serrone (1992), Heine (1993), Gonçalves (1996) e Viera (2004).

8. O termo construção está sendo empregado de modo técnico, em referência ao conceito adotado no modelo de Traugott \& Trousdale (2013), logo, fora de seu sentido genérico, corrente. 
comumente empregados para verificaçáo de composicionalidade de uma construção, e que foram adotados neste estudo.

Já com relação ao aspecto, esse trabalho segue a classificação proposta por Castilho (1968: 14, 51) e Travaglia (2015:84), para os quais o aspecto verbal se caracteriza como acabado (perfectivo) ou inacabado (imperfectivo), sendo este último, foco deste trabalho, subdividido ainda em inceptivo (duração vista em seu início), cursivo (duração vista em seu meio) e terminativo (duração vista em seu término). Nas construçôes aqui classificadas como imperfectivas cursivas, a duração da ação verbal se apresenta em curso, em desenvolvimento, náo se conhecem os limites da ação (início e fim). O aspecto cursivo é tomado, então, na visão desses autores e na deste trabalho, como uma qualidade do tempo que caracteriza a duração de uma ação verbal, se relacionando, portanto, à situação interna da ação verbal. Para este último uso, a literatura galega fala, porém, apenas em aspecto imperfectivo (Freixeiro Mato 2002: 274) ou em imperfectivo durativo (Rojo 1974: 102; Osório \& Vázquez Diéguez 2018: 88). Apesar dessas especificaçôes terminológicas, a interpretação semântica dos dados permite dizer que esses casos são equivalentes, como também provam as palavras de Rojo (1974: 102-103): "estar + gerundio espresa una acción que posee aspecto imperfectivo, que se está desarrollando en el momento del que se habla.”. Ainda segundo este autor:

Tienen aspecto imperfectivo aquellas formas verbales que expresan la acción en su duración, en cuanto procesos que se están desarollando o son considerados de este modo en el momento a que se refiere el hablante. Las construciones perifrásticas que expresan primariamente aspecto imperfectivo en gallego pueden dividirse en dos grandes grupos: a) auxiliar + gerundio [...] e b) auxiliar + a+ infinitivo. (Rojo 1974: 101)

Para Rojo, no primeiro grupo das perífrases imperfectivas de valor durativo, estariam os auxiliares estar (estado), andar, levar, ir, vir (movimento) e seguir (continuativo); já no segundo, estariam os auxiliares estar, andar, seguir, ser (Rojo 1974: 101, 102). Porém, como mostrado na introdução deste texto, este trabalho focalizará apenas as imperfectivas (cursivas) formadas pelos auxiliares estativos, estar e ficar, combinados ao gerúndio.

Desse modo, construçóes foco deste estudo, como "estou lendo um livro" ou "fico lendo o livro", são classificadas como construçôes perifrásticas marcadoras de aspecto imperfectivo cursivo, pois a combinação dos auxiliares estar/ficar com os verbos principais no gerúndio forma um "todo" responsável por expressar que a ação verbal está em seu curso, isto é, não se concluiu e se desconhecem o seu início ou fim. 


\section{Metodologia}

A análise deste trabalho se baseia numa abordagem mista, quantitativa e qualitativa, tendo a primeira o papel de apoiar esta última, foco deste trabalho. Essa análise se deu a partir da coleta de dados reais do galego e de consideraçóes da literatura dessa língua para o fenômeno em questáo. Ela se centra num recorte temporal mais recente, especificamente nos séculos XX e XXI, pois neste período a construcionalizaçáo dessas construçôes em análise já havia se processado no português (Oliveira 2018), estando elas, então, em fase de mudança construcional (pós-construcionalização). Também por se acreditar que, nesta época, se possa falar com mais segurança em textos escritos tipicamente brasileiros, o que permite fazer a comparação aqui pretendida entre o uso da construção perifrástica no Brasil e na Galícia.

Os dados do galego foram coletados em amostras de dois bancos de texto, o Tesouro Informatizado da lingua galega (TILG) e o Corpus de referencia do galego actual (CORGA). É importante lembrar que esses corpora são formados por diferentes gêneros textuais escritos, o que pode limitar a comparação entre essas cronologias.

Segundo informações da própria base do corpus, o TILG (versão 4.1) corresponde a um corpus histórico de textos da língua galega produzidos entre 1612 e 2013 (século XVII ao XXI), compreendendo, portanto, a Idade Moderna e Contemporânea. Foi desenvolvido pelo Instituto de Lingua Galega com o financiamento da Direçáo geral de Política Linguística da Xunta de Galicia. Segue o modelo de busca de palavras, podendo ser por lemas/ elementos gramaticais ou palavras gráficas, o qual permite coletar dados refinados quanto às suas anotaçóes morfossintáticas. A seleção dos dados foi feita por um século inteiro, do primeiro ao seu último ano (Ex.: 1901-2000), a partir da busca por estarlficar em suas diferentes conjugaçóes. A etapa seguinte foi selecionar 3.800 ocorrências de cada um deles por século. Dessas ocorrências foram levantados todos os casos em que eles eram seguidos de gerúndio, e selecionados para a análise apenas aqueles que correspondessem a construçôes perifrásticas.

O CORGA corresponde, por sua vez, a um corpus documental de textos representativos da língua galega atual, do período de 1975 até 2016 (séculos XX e XXI), que permite coletar dados por diferentes meios de busca (palavras ortográficas, elementos gramaticais, lemas, hiperlemas e outros). Este corpus foi utilizado nesta análise apenas para o século XXI (de 2001 até 2016).

O método utilizado para identificação dos dados foi a busca de palavras ortográficas, que, como já sinalizado, ficou restrita a 3.800 ocorrências ${ }^{9}$ de estar ou ficar por século, em suas diferentes conjugaçóes verbais, somando 7.600 dados de cada um deles, dos quais se selecionaram as construçóes em análise. Já os resultados dessa busca foram organizados a partir do critério de concordância.

9. Este recorte se deu pelo fato de só encontrarmos 3840 ocorrências de ficar no século XXI (20012016) nas amostras analisadas. 
Para o tratamento quantitativo dos dados, recorreu-se ao programa $R$ (versão 3.4.2), que foi empregado neste primeiro momento somente para o levantamento das ocorrências e apresentação das porcentagens para cada fator analisado. Seus resultados serão apresentados apenas para fins ilustrativos, de modo a auxiliarem a análise qualitativa aqui proposta. Por esta razão também, a verificação da relevância da atuação de cada elemento característico das alteraçôes da construção será feita apenas em linhas gerais, a partir do que os valores percentuais e absolutos permitirem inferir.

Quanto à análise do fenômeno, é de se esperar, dado o fato de a construção corresponder a composiçóes verbais, que uma alteração em posiçóes argumentais possa ajudar a explicar as mudanças dessas construçóes. Perda de restriçóes na seleção do sujeito quanto à sua animacidade, por exemplo, pode indicar ampliação de escopo de uso dessas construçóes e, consequentemente, avanço no processo de mudança e expansão da rede construcional em análise. Uma seleção mais rica de tipos semânticos na posição do verbo principal da construção perifrástica também pode apontar para extensão de uso da construção, e maior esquematicidade da mesma, o que também sinaliza para adiantamento no processo de mudança. A ausência de elementos intervenientes entre as partes que constituem a construçáo pode, ainda, indicar maior integração entre elas, que passam cada vez mais a serem entendidas como um bloco único (uma construção). Em outras palavras, pode revelar, neste último caso, uma perda de composicionalidade, um dos requisitos para se atestar o avanço da mudança linguística. Nos primeiros casos, haveria também um aumento de produtividade nos termos de Himmelman (2004), tendo em vista o alargamento de uso da construçáo, o que também tem sido apontado como um indicativo de progresso da mudança.

Para finalizar esta seção, cumpre salientar alguns aspectos de natureza formal que serão adotados no tratamento dos exemplos ao longo deste texto. As perífrases serão destacadas em cada caso em itálico e o fator em análise no momento virá em negrito. Havendo um terceiro fator a se destacar, este virá sublinhado e especificado na discussão do exemplo.

\section{Categorias de análise}

Cabe aqui apresentar brevemente os fatores utilizados para a observação das alteraçôes de esquematicidade, produtividade e composicionalidade das construçóes, e, consequentemente, avaliação de seu processo de mudança, como se discutiu anteriormente.

A classificação dos verbos em tipos semânticos partiu da proposta de Sigiliano (2013: 126), que dividia os verbos em treze categorias: manipulativos (Ex.: ordenar, persuadir), desiderativos (Ex.: querer, desejar), perceptivos (Ex.: ver, sentir), processo mental (Ex.: saber, compreender), atitude proposicional (Ex.: achar, acreditar), de 
elocução (Ex.: dizer, falar), de deslocamento (Ex.: ir, entrar, andar), de ação (Ex.: fazer, pegar), estativo atributivo (Ex.: ser, Ex.: estar, ficar), fenômeno da natureza (Ex.: chover, ventar), mudança de estado (Ex.: secar, passar o tempo), de sentimento (Ex.: amar, odiar) e emotivo (Ex.: chorar, entristecer). Entretanto, dadas as adaptaçóes necessárias a este trabalho, resultou em quatro conjuntos de tipos semânticos verbais que compartilhassem entre si certas semelhanças mais gerais: cognitivos, estativos, de deslocamento/mudança de estado e de ação, exemplificados a seguir:

(1) ¿E non decías que estabas estudiando? (Teatro em prosa / 1914-TILG- Séc. $\mathrm{XX)}$ [AÇÃO]

(2) Os mais ficaban traballando os eidos. (Novela /1928- TILG- Séc. XX) [AÇÃO]

(3) Bota outra rolda, Eusebio, que estamos quedando secos. Mira eses pobres da obra de aí en fronte. (Novela / 2002-TILG- Séc. XXI) [ESTATIVO]

(4) Ficarei agardando a resposta no domingo. (Poesia de autor / 1987- TILGSéc. XX) [ESTATIVO]

(5) Estaba deseando chegar á súa casiña pr'apestar ó curandeiro [...]. (Relato curto / 1908- TILG- Séc. XX) [COGNITIVO]

(6) [...] que pinga a campá do ceo ficou chorando no campo o enorme e viúdo. (Poesia de autor/ 1928- TILG-Séc. XX) [COGNITIVO]

(7) [... ¿Viches por aí ó meu fillo? ... ¿ qué dis? ... ¿ qu'estaba saíndo da taberna da Vitorian? [...]. (Relato curto / 1901- TILG- Séc. XX) [DESLOCAMENTO]

(8) [...]-Non tremas, medorento, que desta non vas parir - dille meu pai ao diasco, que non se fintaba moito do irmán. - Parir non ... Pro non anceio ficar amolecendo aí todo o inverno ... [...]. (Novela / 1973- TILG- Séc. XX) [DESLOCAMENTO/mudança de estado $]^{10}$.

Nesta nova categorização, que partiu da interpretação semântica dos verbos nos contextos de uso, os tipos foram agrupados segundo suas semelhanças de comportamento, o que, inevitavelmente, abriu espaço para exemplos menos prototípicos, sobretudo se se considera a hipótese de que a redução do número de categorias resulte em maior dificuldade de agrupamento de membros que compartilhem muitas características comuns. Isso pressupóe classes mais abertas, com constituintes mais variados entre si. Isto significa uma divisão gradativa, o que faz com que verbos como estudar se aproximem tanto dos tipos ação (por se tratar do ato de um sujeito agenti-

10. Náo foi encontrado nenhum caso de perífrase verdadeira de ficar com V2 de deslocamento físico-espacial. Nessas ocorrências, ficar e gerúndio pareciam ter usos independentes: "[...] Entón a xente deixaría de ficar ao lonxe, alonxandose, para voltar ao seu lar e deschuír as portas [...]". (Novela / 1981- TILG- Séc. XX). 
vo de realizar uma tarefa: estudar uma matéria, um assunto ou material) quanto dos cognitivos (pelo resultado ou efeito do ato de estudar: saber, compreender, entender).

Segundo essa classificação, sob o rótulo de cognitivos estão os desiderativos, processos mentais, atitudinais, sentimentais, emotivos, perceptivos, comportamentais, manipulativos e de elocução, por se referirem, em alguma medida, a processos cognitivos mais gerais. Os tipos posse, existenciais e estativos se agruparam no tipo estativo, por remeterem a estados, à permanência do sujeito. Também foram condensados os tipos "mudança de estado" e "deslocamento", formando a terceira categoria (deslocamento/mudança de estado). Verbos desse tipo, em oposição aos estativos, remetem a movimento, mudança, ao deslocamento físico ou de estado. No quarto e último grupo, ficaram os verbos do tipo ação, que correspondem, na classificação de Halliday \& Matthiessen (2004), aos processos materiais. Equivalem a situaçóes em que um agente (sujeito/ator) realiza uma ação, podendo haver, ainda, uma meta (objeto/complemento) nesse processo, como em: "O homem (ator) fez (ação) a comida (meta)".

Já o critério de animacidade é tomado aqui com referência à noção de agentividade. Agentividade é um conceito amplo e ainda pouco consensual na literatura, geralmente tratado em oposição à ideia de passividade. Fazemos referência neste trabalho à ideia mais geral de agentividade, vista sob seu aspecto semântico, que se refere ao papel ativo do sujeito da frase em relação à noção expressa pelo verbo. Assim, sujeitos mais agentivos seriam aqueles que desempenham, controlam uma ação ou produzem um efeito. A partir desta divisão, haveria o grupo de sujeitos [- animados], como em (9) e (10), e o dos [+animados], (11) e (12).

(9) S'era torto, ou era dreito. Cando á costa chegamos, Ond'o lugar se perdía; Sentate, mira o zoán, Que xa está chegand’o día. (Poesia de autor / 1911TILG- Séc. XX)

(10) A colleita que ía para bo ano fica poñendo a miseria nos ollos [...]. (Novela / 1986-TILG- Séc. XX)

(11) [...] O que fixen ou estou facendo, como a Escola de Belas Artes ou o Mercado de Abastos, son o resultado de gañar concursos. (Jornal / 2001- CORGA-Séc. XXI)

(12) Despois de moitas horas pelidando un co outro quedamos en que iría un ver ó bispo mentres o outro ficaba vixiando. (Novela / 1984- TILGSéc. XX)

Como é possível verificar em (9) e (10), os seus respectivos sujeitos, $o$ dia e $a$ colheita, são inanimados, não humanos e não agentivos, correspondendo, portanto, à categoria dos [-animados] na classificaçáo deste trabalho. Por outro lado, os sujeitos de (11) e (12), respectivamente eu (oculto/desinencial) e o outro, sáo animados, de natureza [+humana] e agentivos, recebendo, então, a classificação de [+ animados] neste trabalho. 
Além disso, sob o rótulo "outros" foram reunidos os casos de oração sem sujeito e de sujeito indeterminado (mesmo que este último aponte para um valor [+animado]), que, apesar de não serem o foco desta análise, permitem observar também expansōes/restriçóes da perífrase.

O fator material interveniente, por sua vez, tem sido usado nos estudos, a exemplo de Travaglia (2007) e Tavares (2018), para revelar níveis de integraçáo de uma construção, e a leitura automatizada (conjunta) ou somatória (composicional) das partes que a compóe. Diferentes elementos morfológicos e de diferentes tamanhos (extensão gráfico-fonológica) podem ocorrer entre V1 e V2 separando os elementos da perífrase. A depender da extensão (número de sílabas) e da natureza morfossintática desses elementos (oblíquos, sintagmas, oraçóes intercaladas, sujeito, circunstanciais de lugar, tempo, modo etc.), a leitura perifrástica se enfraquece ou não, ou seja, a significação do complexo verbal se revela mais disjunta ou conjunta.

$\mathrm{Na}$ análise deste fator, não se esperam grandes oraçóes intercalando os elementos da perífrase, o que tenderia a enfraquecer a leitura perifrástica, mas sim elementos de pequena extensão silábica (até 2 sílabas), como clíticos (15). Esse número de elementos, porém, não é categórico, já que a análise se dá mais por uma interpretação semântica (manutenção ou não da leitura perifrástica), somada à observação da natureza morfossintática desse material.

Estudos anteriores na área, como Travaglia (2007) e Tavares (2018), têm revelado que quanto maior a integração e leitura conjunta da perífrase menor a possibilidade de sua interrupção, e que elementos que remetam a contextos anteriores ao da nova construção também são menos esperados. No caso das perífrases em análise neste trabalho, esses elementos seriam os de natureza adverbial, sobretudo locativos, e de maior extensão morfofonológica, pois apontam para usos anteriores ao perifrástico, sendo interpretados como possíveis argumentos de estar e ficar em seus empregos iniciais (relacionais de lugar, tempo, modo etc.). Isso permitiria que esses verbos fossem vistos de forma autônoma/disjunta em relação ao gerúndio. Logo, a menor ocorrência de elementos dessa natureza nas construçóes em análise pode indicar que elas estejam mais consolidadas, enquanto perífrases, na língua.

Nos exemplos abaixo, é possível notar uma relação entre a natureza do material e a leitura mais ou menos ambígua da construção entre uma estrutura complexa (nuclear + oração hipotática/ reduzida adverbial) e uma simples (construção perifrástica). Nas construçôes com elemento interveniente de natureza circunstancial (lugar, modo, tempo, por exemplo), como ocorre mais frequentemente com $[\text { ficar }+\mathrm{X}-n d o]_{\text {cursivo }}$, a ambiguidade se intensifica, levando a uma leitura de duas oraçóes justapostas. Isso mostra que nesses casos há maior composicionalidade na construção, ou seja, retração do processo de mudança. Os dados (13) e (14) mostram esses casos por meio da interrupção da perífrase por uma locução adverbial de lugar composta por dois elementos que totalizam quatro sílabas em (13) e por uma locução prepositiva de modo em (14), que, apesar de pequena extensão (duas sílabas), remete ao contexto relacional de ficar. 
(13) O pequeno Daniel, fica na cantina atesourando o segredo, recuperando a melancolía homicida das imaxes arrepiantes. (Novela / 2001- CORGASéc. XXI)

(14) A Esther, ao entrar, fica de pé mirando para os dous [...]. (Novela / 1986TILG- Séc. XX)

Se, por outro lado, o elemento interveniente é um clítico acusativo, como em (15), reflexivo/dativo (16), partícula apassivadora ou sujeito, casos predominantes nas construçóes de estar, como mostram os exemplos a seguir, a leitura do gerúndio como parte de uma construção perifrástica é mantida, desfazendo-se possíveis ambiguidades, sobretudo em línguas como o galego, que permitem, com frequência, a posposição do sujeito ou a junção do clítico ao verbo auxiliar.

(15) Estouno desexando. (Novela / 2001-CORGA- Séc. XXI)

(16) [...] Algún estarase preguntando como se pode poñer alguén a investigar estas cousas. (Ensaio / 2011- CORGA-Séc. XXI)

\section{Resultados}

A estrutura estar/ficar + gerúndio, a par de uma leitura de construção de aspecto cursivo, integra diferentes construçóes: uma oração complexa formada por uma oração principal seguida de uma reduzida adverbial de gerúndio, e uma estrutura ambígua, que aponta tanto para leitura de duas oraçóes justapostas (duas construçóes independentes) quanto para uma construção perifrástica (um único bloco, uma unidade). Quanto aos casos ambíguos, também já foram sinalizados na literatura desta língua:

En el uso moderno, hemos de señalar en primer lugar la posibilidad de la disociación. En este tipo de construcciones, el auxiliar estar tiene un valor plenamente estativo con respecto a una determinación y, al mismo tempo, incide sobre un gerundio contituyendo perífrasis. Esta determinación puede ser espacial, como en: Fun en procura do Lombo de palla e do Daniel, que estaban na cociña falando coas mulleres. (Á lus do candil, 50). También puede ser temporal: Veu medrar á cidade. Entrou nela de corazón. Estivo corentesete anos aprendéndoa. (H. de emigrantes, 14). O de otros tipos: Meu mociño foise lonxe / a gañar pró casamento; / este morto ou traballando, / quedou no meu pensamento. (C. sociales, número 17) [...] Lo más corrientemente expresado es un aspecto imperfectivo referido a procesos de duración relativamente corta. (Rojo 1974: 103) 
Por essa razão, ainda no período atual, são atestados casos nitidamente anteriores aos perifrásticos nas duas línguas em análise, como em (17), no qual é possível interpretar o gerúndio como um modificador de ficar, e não como um V2 de uma perifrástica, assim como ambíguos ((18) e (21)) ou, ainda, exemplos prototípicos de uma construção perifrástica cursiva de gerúndio já consolidada ((19) e (22)), como se observa a seguir.

(17) Gabriel fica a masticar a galleta ollando fixo para Luz [...]. (Obra de teatro / 2005- CORGA- Séc. XXI)

(18) O policía afástase un par de pasos e fica calado mirando como o celador sae tras dela pola porta arrastrando o maquinucho ruidoso. (Obra de teatro / 2006- CORGA- Séc. XXI) [AMBÍGUO]

(19) Os mais ficaban traballando os eidos. (Novela / 1928- TILG- Séc. XX)

(20) Ali están, el e máis ela, falando normalmente, tan serios eles, tan recatados e, de súpeto ... i veña! desmelénanse e póńense a cantar. [...]. (Obra de teatro / 2005- CORGA- Séc. XXI)

(21) O cabaleiro, que se lle conocía que estaba alí ardendo desque vira atravessar as duas sombras [...]. (Novela / 1905-TILG- Séc.XX) [AMBÍGUO]

(22) Facerás ben, e non tardes que xa debe estar chegando. (Teatro em prosa / 1917- TILG- Séc. XX)

É possível observar com esses dados que não é tarefa tão simples distinguir os casos de oração complexa ((17) e (20)) e ambíguas ((18) e (21)) daqueles de oração simples (perífrase cursiva de gerúndio) ((19) e (22)), sobretudo em função da presença de elementos intervenientes entre V1 e V2, o que sugere etapas intermediárias à formação da perífrase. Parece haver, portanto, um contínuo entre esses três grupos (oração complexa>casos ambíguos >construçôes perifrásticas cursivas) e a sinalização do possível caminho precedente dessas perifrásticas.

\subsection{Tipo semântico de V2}

Com relação aos tipos semânticos de V2, a análise aponta para um uso mais recorrente de verbos de ação e cognição em ambas as construções em comparação com os demais tipos. É verificável, no entanto, no século atual, uma espécie de distribuição particular desses dois tipos em cada construçáo, predominando o cognitivo na construção $[f i c a r+\mathrm{X}-n d o]_{\text {cursivo }}$ e o ação na construção $[e s t a r+\mathrm{X}-n d o]_{\text {cursivo }}$, como revela o Quadro 1. 


\begin{tabular}{|c|c|c|c|c|c|c|c|c|}
\hline \multirow[t]{3}{*}{ Tipo de V2 } & \multicolumn{4}{|c|}{ [ESTAR + X-NDO] } & \multicolumn{4}{|c|}{ [FICAR + X-NDO] } \\
\hline & \multicolumn{2}{|c|}{$\mathrm{XX}$} & \multicolumn{2}{|c|}{ XXI } & \multicolumn{2}{|c|}{$\mathrm{XX}$} & \multicolumn{2}{|c|}{ XXI } \\
\hline & F.A & $\%$ & F.A & $\%$ & F.A & $\%$ & F.A & $\%$ \\
\hline Ação & 188 & $39,2 \%$ & 177 & $49,4 \%$ & 51 & $40,8 \%$ & 17 & $29,8 \%$ \\
\hline Estado & 64 & $13,4 \%$ & 69 & $19,3 \%$ & 14 & $11,2 \%$ & 10 & $17,5 \%$ \\
\hline Cognição & 201 & $41,9 \%$ & 86 & $24 \%$ & 59 & $47,2 \%$ & 30 & $52,6 \%$ \\
\hline Deslocamento & 26 & $5,4 \%$ & 26 & $7,3 \%$ & 1 & $0,8 \%$ & 0 & - \\
\hline Total de dados & \multicolumn{2}{|c|}{479} & \multicolumn{2}{|c|}{358} & \multicolumn{2}{|c|}{125} & \multicolumn{2}{|c|}{57} \\
\hline
\end{tabular}

Quadro 1. Tipo semântico de V2 em galego"11 (adaptado de Oliveira 2018: 221).

Os dados mostram que, inicialmente, todos os tipos poderiam ocorrer com ambas as construçóes. Na passagem de um século a outro, porém, essa distribuiçáo foi se rearranjando. Nas construçôes com estar, houve um aumento de uso, em termos percentuais, dos tipos ação, estado e deslocamento, e diminuiçáo (de quase $18 \%$ ) de emprego do cognitivo. Com relação à construção com ficar, este aumento se deu com os tipos estado e cognitivo, e a diminuição, com os de deslocamento e ação, sobretudo este último, que teve uma queda de $10,7 \%$ de seu emprego de um século a outro.

Comparativamente, nas construçóes com estar, enquanto o tipo ação aumentou sua ocorrência, o cognitivo reduziu, ao passo que, nas construçóes com ficar, ocorreu o inverso: o cognitivo aumentou enquanto o ação reduziu seu emprego na passagem de um século a outro. Além disso, foi notada uma restrição de uso de verbos de deslocamento/mudança de estado com a construçáo com ficar (apenas uma ocorrência e somente no século XX, sendo esta do tipo mudança de estado (08). Uma separação desta categoria verbal reforçaria ainda mais a aparente restrição de seleção desta construção quanto aos verbos de movimento, sinalizando uma conservação maior da semântica original de ficar (estativo), e, portanto, pouco avanço de mudança em termos de composicionalidade.

Em termos qualitativos, uma diferença mais expressiva pôde ser percebida entre essas construçóes. É o caso do emprego de certos verbos em particular, sobretudo do tipo cognitivo, como saber. Na construção com ficar, foi observado que a perífrase perde sua leitura cursiva quando preenchida por esse verbo e passa a significar 'torna-se a partir daquele momento'/ 'passe a saber':

(23) Hai razón, os números son repetitivos como no circo, mais fique sabendo que, naquela hora de viruxe do nordés e calor interno, naquel baño

11. FA = Frequência absoluta. Lembro aqui que os dados por século em cada quadro correspondem apenas aos casos perifrásticos identificados do total de ocorrências de cada verbo em seus múltiplos empregos. Por esta razão, a soma das ocorrências não totaliza 7.600. 
xaponés de temperaturas extremas, a revelación [...]. (Relato curto / 2011CORGA- Séc. XXI)

Neste exemplo, a leitura cursiva da perífrase é desfeita, e parece haver aqui um caso de expressão idiomática ${ }^{12}$. Nas construçôes com estar este comportamento não foi verificado e a marcação cursiva foi mantida nesses contextos.

A leitura cursiva também parece se enfraquecer naquela construção em alguns casos em que o V2 é ocupado pelo verbo ser, recebendo uma interpretaçáo de 'tornar-se a partir daquele momento', 'passar a ser', ou seja, de transformação ou mudança de estado:

(24) [...] Noticia terrible, acaso tan terrible como a morte da súa nai. Sentiu como ficaba na máis fonda soidade. Sen ninguén con quen falar, sen ningún amigo ao que acudir. E era, sen dúbida, o final dunha etapa. Despois daquilo o seu pasado ficaba sendo un bosque mesto e escuro que xa non podería compartir con ninguén. (Novela / 1990- TILG- Séc. XX)

Se, por um lado, as construções perifrásticas de ficar apresentam certas restriçôes de uso nesse ambiente, as de estar, em contrapartida, revelam ampliação de seu rol de contextos de ocorrência. Confrontando essas duas construçôes, é verificável um alargamento do contexto sintático desta última com a possibilidade de inclusão de um modal do tipo epistêmico ${ }^{13}$ na sua posição à esquerda, como visto a seguir:

(25) Outra, o demonio que tal truxo, debe estar ardendo no inferno. (Relato curto / 1901- TILG- Séc. XX)

Neste exemplo, a colocação do modal debe encabeçando a perifrástica de estar permite dizer que ela pode estar avançando na direção da mudança em relação à construção com ficar, que não apresentou dados dentro desse mesmo contexto na amostra analisada. Não significa, porém, que dados como esse não sejam admitidos nesta língua com esta construçáo, mas que sua baixa recorrência de uso aponta para sua pouca produtividade em variados contextos.

12. Termo entendido aqui como "construção cristalizada", que corresponde a um sentido convencionalizado para uma expressão cujas partes não podem ser lidas literalmente, mas sim em seu todo, assumindo um sentido estabelecido socialmente pelo grupo de fala que a emprega. Trata-se de expressôes típicas de determinada região, que geralmente não podem ser traduzidas literalmente.

13. Segundo Palmer (1979; 1986), os modalizadores podem ser distribuídos em deônticos (obrigatoriedade, permissão ou proibição), epistêmicos (certeza, possibilidade, probabilidade) e dinâmicos (capacidade, habilidade). 
Quanto à posição à direita da perífrase, os dados revelaram que as construçóes $[\text { estar }+\mathrm{X}-n d o]_{\text {cursivo }}$, quando preenchidas por ser na posição V2, admitiam, além dos complementos SN (sintagmas nominais) e Sadj (sintagmas adjetivais), adjetivos de natureza deverbal, como no dado (26) abaixo, o que permitiu à construçáo a ocorrência numa estrutura de voz passiva mantendo a marcaçáo aspectual cursiva, a exemplo de (26) e (27).

(26) [...] E moitas obras galegas están sendo traducidas a varios idiomas. (Jornal / 2005- CORGA- Séc. XXI)

(27) [...] O presidente Zardari evitara ata agora ratificar un pacto que tamén está sendo duramente criticado tanto dentro de Paquistán como por parte da comunidade internacional. (Jornal / 2009- CORGA- Séc. XXI)

Em (27), fica ainda mais clara a leitura passiva da estrutura, dada a presença de um agente da passiva ("por parte da comunidade internacional"), compondo uma estrutura típica de construção passiva.

\subsection{Animacidade do sujeito}

No que diz respeito à animacidade do sujeito, a análise revelou uma predominância do [+animado], tanto com as construçóes de estar (93\% de uso no Séc. XX e 82\% no Séc. XXI) quanto com as de ficar (92\% e 93\% de ocorrência nos séculos XX e XXI respectivamente), como mostra o Quadro 2 a seguir, apesar de a construçáo com estar apontar para uma maior flexibilização do preenchimento do sujeito na passagem de um século a outro.

\begin{tabular}{|c|c|c|c|c|c|c|c|c|}
\hline \multirow{3}{*}{$\begin{array}{c}\text { Animacidade } \\
\text { do } \\
\text { Sujeito }\end{array}$} & \multicolumn{4}{|c|}{ [ESTAR + X-NDO] } & \multicolumn{4}{|c|}{ [FICAR + X-NDO] } \\
\hline & \multicolumn{2}{|c|}{ XX } & \multicolumn{2}{|c|}{ XXI } & \multicolumn{2}{|c|}{ XX } & \multicolumn{2}{|c|}{ XXI } \\
\hline & F.A & $\%$ & F.A & $\%$ & F.A & $\%$ & F.A & $\%$ \\
\hline [+animado] & 445 & 93 & 293 & 82 & 115 & 92 & 53 & 93 \\
\hline [-animado] & 33 & 6,8 & 44 & 12,3 & 10 & 8 & 4 & 7 \\
\hline Outros & 1 & 0,2 & 21 & 5,8 & 0 & - & 0 & - \\
\hline Total de dados & \multicolumn{2}{|c|}{479} & \multicolumn{2}{|c|}{358} & \multicolumn{2}{|c|}{125} & \multicolumn{2}{|c|}{57} \\
\hline
\end{tabular}

Quadro 2. Animacidade do sujeito em galego. 


\subsection{Material interveniente}

No que se refere ao fator material interveniente, o Quadro 3 a seguir revela que sua presença foi mais atestada na construção $[\text { ficar }+\mathrm{X}-n d o]_{\text {cursivo }}, \operatorname{com} 27,2 \%$ de casos no século XX e 31,6\% no XXI, o que pode indicar um grau mais elevado de composicionalidade dessa construção em comparação à $[e s t a r+\mathrm{X}-n d o]_{\text {cursivo }}$, que apresentou, no mesmo período, uma taxa menor de emprego, $13,2 \%$ e 18,4\% nos respectivos séculos. É preciso ressaltar novamente que o grau da composicionalidade está associado nesses casos à possibilidade de leitura composicional, em que se somam os valores de cada uma das partes para o cômputo do valor final da construçáo, anulando ou enfraquecendo sua leitura perifrástica/conjunta.

\begin{tabular}{lccccccccc}
\multirow{2}{*}{ Material } & \multicolumn{4}{c}{ [ESTAR + X-NDO } & \multicolumn{3}{c}{ [FICAR + X-NDO] } \\
\cline { 2 - 11 } & \multicolumn{2}{c}{ XX } & \multicolumn{3}{c}{ XXI } & \multicolumn{3}{c}{ XX } & \multicolumn{2}{c}{ XXI } \\
\cline { 2 - 11 } & F.A & $\%$ & F.A & $\%$ & F.A & $\%$ & F.A & $\%$ \\
\hline Presença & 63 & 13,2 & 66 & 18,4 & 34 & 27,2 & 18 & 31,6 \\
Ausência & 416 & 86,7 & 292 & 81,6 & 91 & 72,8 & 39 & 68,4 \\
Total de dados & \multicolumn{2}{c}{479} & \multicolumn{2}{c}{358} & \multicolumn{2}{c}{125} & \multicolumn{2}{c}{57} \\
\hline
\end{tabular}

Quadro 3. Material interveniente.

Quanto à natureza desse material, com $[\text { estar }+\mathrm{X}-n d o]_{\text {cursivo }}$, predominaram os clíticos, pronomes reflexivos (ambos de pequena extensão silábica. Ex.: Ile, no(a), me, che, te; se, me) e os sujeitos, incluindo os pronominais. Já com $[f i c a r+\mathrm{X}-n d o]_{\text {cursivo' }}$, prevaleceram os elementos de natureza adverbial, como circunstanciais de lugar, tempo e modo (geralmente de duas ou mais sílabas: "un momento", "un intre", "de pé", "alî" e outros), havendo ainda muitos casos, no século XX, de adjetivos/particípios e sujeitos intercalando os elementos dessa construçáo, como se verifica, respectivamente, em (28) e (29) a seguir:

(28) O silenzo e mais eu ficamos calados artellando ensoños fanados ... alma nena ; A ti che prego [...]. (Poesia de autor / 1963-TILG-Séc. XX)

(29) [... De Campo redondo tiña de olláparo na parroquia máis próisima chegara xa arrebentando o cabalo para avisar que alí ficaban os visitantes botando unhas verbas aos que saíran a saudá-los. [...]. (Novela / 1951-TILG-Séc.XX)

Cabe chamar atenção também para a distribuição distinta dos tempos verbais nessas duas construçóes, que, apesar de não ser considerado previamente um fator de análise, revelou, no tratamento dos dados, certa sistematicidade de emprego, merecendo um 
maior detalhamento nesta etapa da análise. Nas perifrásticas de estar, predominaram os tempos presente (com 65,3\% no Séc. XX e 71,5\% no Séc. XXI) e imperfeito (com $22,13 \%$ no Séc. XX e 21,2\% no XXI), respectivamente, ao passo que, nas formadas por ficar, os tempos verbais predominantes foram o perfeito (com 37,6\% no Séc. XX e $40,3 \%$ no Séc. XXI) e o presente (com $30,4 \%$ no Séc. XX e 36,8\% no XXI), nesta ordem de recorrência de uso. Isso parece sugerir uma complementariedade de distribuição quanto a este fator entre essas duas construçóes, ajudando a delimitar os contextos típicos para o emprego de uma ou outra, que se alternam nessa língua, de modo geral, na marcação aspectual cursiva, como sumariza o Quadro 4.

\begin{tabular}{lccccccccc}
\multirow{2}{*}{ Tempos verbais } & \multicolumn{4}{c}{ [ESTAR + X-NDO] } & \multicolumn{3}{c}{ [FICAR + X-NDO] } \\
\cline { 2 - 11 } & \multicolumn{3}{c}{ XX } & \multicolumn{3}{c}{ XXI } & \multicolumn{3}{c}{ XXI } \\
\cline { 2 - 11 } & F.A & $\%$ & F.A & $\%$ & F.A & $\%$ & F.A & $\%$ \\
\hline Presente & 313 & 65,3 & 256 & 71,5 & 38 & 30,4 & 21 & 36,8 \\
Pretérito perfeito & 28 & 5,8 & 4 & 1,1 & 47 & 37,6 & 23 & 40,3 \\
Pretérito imperfeito & 106 & 22,1 & 76 & 21,2 & 24 & 19,2 & 7 & 12,3 \\
Futuro & 7 & 1,5 & 19 & 5,3 & 7 & 5,6 & 6 & 10,5 \\
Outros & 25 & 5,2 & 3 & 0,9 & 9 & 7,2 & 0 & - \\
\hline Total de dados & \multicolumn{4}{c}{479} & \multicolumn{3}{c}{358} & \multicolumn{3}{c}{125} & & 57 \\
\hline
\end{tabular}

Quadro 4. distribuição do tempo verbal nas construçôes perifrásticas de estar e ficar ${ }^{14}$.

\section{Convergências e divergências entre o galego e o português do Brasil}

A análise feita até aqui revelou, semelhantemente ao que foi atestado para o português em Oliveira (2018), certas restriçóes nas construçóes $[\text { ficar }+\mathrm{X}-n d o]_{\text {cursivo }}$ quanto ao uso de alguns verbos cognitivos em V2 (23), além de maior fragilidade da leitura cursiva dessa construção quando interrompida por determinados elementos (13). Ademais foi atestado, em ambas as línguas, a possibilidade de modalização da construção $[\text { estar }+\mathrm{X}-n d o]_{\text {cursivo }}$ (26), embora bem menos recorrente e diversificada no galego.

No $\mathrm{PB}$, além de frequentes, os casos de modalização também se mostraram bem variados (pode, deve, parece etc.), o que pode ter favorecido a "abertura" da posição do modal para novos auxiliares, como o $i r$, no presente do indicativo, para expressar um novo tipo de modalização, a de "futuro epistêmico" (Oliveira 2018), como em: vou estar

14. Sob o rótulo "outros", estáo os casos de mais-que-perfeito ou de forma nominal, como em: "mais ¿por que as ideas rexionalistas han estar agardando a que veña ninguén levá-las pra onde quixer? [...]” (Jornal / 1912-TILG- Séc. XX). 
enviando, na qual a ação verbal é colocada em termos de possibilidade, o que a literatura chama de construçóes de gerundismo. Nesses casos, a construção parece ganhar um valor pragmático de protelação/postergação do cumprimento da ação verbal ou uma atitude de descomprometimento do falante quanto à execuçáo, ao menos imediata, da ação, o que explicaria a avaliação negativa dessa construção na língua pelo senso comum e pelos compêndios gramaticais. Além disso, essa construção também é apontada na literatura como recurso para sinalizar polidez na fala (Possenti 2005), o que reforça, mais uma vez, a formação de um novo pareamento forma-significado.

Ainda cabe enfatizar que, à semelhança do português de Portugal, o galego também recorre, ainda que em menor grau, aos types [estar+ $a+$ infinitivo] e [ficar+ $a$ +infinitivo] para expressar o aspecto cursivo, contrariamente ao $\mathrm{PB}$, que opta pela construção de gerúndio.Tal fato, como já sinalizado anteriormente, poderia ajudar a explicar por que o gerundismo é uma construção linguística tipicamente brasileira, "desconhecida" entre a maioria dos falantes do galego atual, indicando a maior esquematicidade da construção $[\text { estar }+\mathrm{X}-n d o]_{\text {cursivo }}$ no PB.

A hipótese por trás dessa afirmação é a de que essa produtividade possa ter sido limitada, no galego, pela concorrência de emprego entre as construçóes cursivas com gerúndio e as cursivas com infinitivo gerundial, o que, inevitavelmente, diminuiria a frequência de uso da primeira, se comparada ao PB, que só realiza aquela. Essa consideração se apoia na crença de que a alta frequência de uso das construções de gerúndio no $\mathrm{PB}$ tenha permitido seu maior esvaziamento semântico, sua alta, frequente e diversificada modalização e, consequentemente, seu recrutamento para novos contextos, como o de gerundismo. Estudos na área também mostram que a frequência de uso de uma construção tem significativa importância para avanço de mudança linguística (Bybee 2003, 2010).

No que diz respeito à natureza do sujeito, foi constatado em ambas as línguas uma ampliação de uso dos [-animados] na construçáo [estar $+\mathrm{X}-n d o]_{\text {cursivo }}$ no século atual, de $6 \%$ no português e de $11,1 \%$ no galego, embora percentualmente este uso seja mais frequente no português, como mostra o Quadro 5 a seguir. Além disso, no século atual, sobretudo no português, como revelou Oliveira (2018), também foi verificada uma maior variedade tipológica dos sujeitos (diversificadas estratégias de indeterminação do sujeito, abrangência maior de casos com sujeito inexistente), como mostram os exemplos na sequência.

(30) Estase xogando cos nosos dereitos, apuntou Ortega. (Jornal/ 2009- CORGA- Séc. XXI)

(31) Díxenche que estaban cambiando a pechadura do Rexistro, ¿non?. (Novela / 2002- CORGA- Séc. XXI)

(32) [... As desigualdades sociais van incrementar" e o "conflito social" pode converterse nunha realidade como está ocorrendo en Grecia ou Francia. (Jornal / 2009- CORGA- Séc. XXI) 
São identificadas, nesses exemplos, construçôes sem sujeito (32) e construçóes com sujeito indeterminado, pela presença do índice "se" (30) ou pelo verbo na $3^{\mathrm{a}}$ pessoa do plural (31). Por outro lado, esses usos não foram atestados nas amostras para $[\text { ficar }+\mathrm{X}-n d o]_{\text {cursivo }}$ em nenhuma das duas línguas. Isso ilustra, principalmente em termos qualitativos, uma ampliação de uso das construçóes perifrásticas com estar, tendo em vista esse alargamento semântico-funcional(sintático) da categoria do sujeito.

Quanto ao tipo verbal, um ponto a ser destacado é a predominância dos estativos e dos verbos de ação, nas construçóes do português, sobretudo nas de ficar, ao passo que, no galego, há a predominância dos verbos de tipo cognitivo e ação. Além disso, diferentemente do português, foi identificado no galego um uso de V2 do tipo deslocamento/ mudança de estado também na construção $[\text { ficar }+\mathrm{X}-n d o]_{\text {cursivo }}$. Essa aparente restrição pode estar relacionada à natureza deste auxiliar, que pressupóe permanência, ausência de movimento. Além disso, este número poderia ser nulo se a classificaçáo tipológica do verbo separasse os casos de mudança de estado dos de deslocamentos físico-espaciais.

Uma classificação mais detalhada dos tipos semânticos verbais e o levantamento de mais caracterizadores de uso dessas construçóes também poderiam apontar resultados mais pormenorizados dessas duas línguas quanto ao fenômeno estudado.

Já com relação à presença e natureza do material interveniente, os dados sugerem uma tolerância maior do galego à interrupçáo da perífrase, especialmente na de ficar, em termos de frequência token. Nessa língua, esses elementos também foram de maior extensão silábica/morfofonológica e remetiam aos usos originais de ficar e estar, o que será demonstrado com mais detalhes no quadro comparativo do galego e do português na sequência.

Outra diferença entre essas duas línguas, dentro do fenômeno investigado, concerne à quantidade e natureza do material que interrompe a sequência perifrástica no galego. No português, o percentual de inserção de elementos entre os itens da perífrase foi de 4,3\% e 11,3\% para as construçôes com estar nos séculos XX e XXI, respectivamente, e de 7,14\% e 16,6\% nas construçôes com ficar para este mesmo período. Já no galego, esses valores foram de 13,2\% e 18,4\% para as construçóes de estar, nos séculos XX e XXI, contra 27,2\% (Séc. XX) e 31,6\% (Séc. XXI) para as construções com ficar. É notório que não só é mais frequente a inserção de elementos na perífrase no galego, principalmente na construção com ficar e no século atual, como também há diferença na natureza desse material.

No português há pouca ocorrência de elementos intervenientes e, quando manifestados, costumam ser de pequena extensão morfofonológica / silábica. Predominam pronomes reflexivos, Sprep e alguns poucos clíticos. No galego, porém, além de mais recorrentes, são maiores em extensão silábica (maior número de morfemas), podendo incluir sintagmas nominais/adjetivais inteiros. É importante lembrar a discussão levantada anteriormente a respeito dos efeitos de leitura da construçáo, mais ou menos composicional, a depender da natureza morfológica deste material. 


\begin{tabular}{|c|c|c|c|c|c|c|c|c|c|}
\hline \multirow{3}{*}{\multicolumn{2}{|c|}{$\begin{array}{l}\text { Construçóes } \rightarrow \\
\text { Idiomas } \rightarrow \\
\text { Séculos } \rightarrow \\
\text { Fatores } \downarrow\end{array}$}} & \multicolumn{4}{|c|}{ [ESTAR + X-NDO $]$} & \multicolumn{4}{|c|}{$[\mathrm{FICAR}+\mathrm{X}-\mathrm{NDO}]$} \\
\hline & & \multicolumn{3}{|c|}{ PORTUGUÊS } & \multicolumn{2}{|c|}{ GALEGO } & \multicolumn{2}{|c|}{ PORTUGUÊS } & \multirow{2}{*}{$\frac{\text { GALEGO }}{\text { XXI }}$} \\
\hline & & $\mathrm{XX}$ & XXI & $\mathrm{XX}$ & XXI & $\mathrm{XX}$ & XXI & $\mathrm{XX}$ & \\
\hline $\begin{array}{l}\text { Animacidade } \\
\text { do sujeito }\end{array}$ & [+Animado] & $69 \%$ & $63 \%$ & $92,9 \%$ & $81,8 \%$ & $78,6 \%$ & $100 \%$ & $92 \%$ & $93 \%$ \\
\hline \multirow{4}{*}{ Tipo de V2 } & Ação & $57,8 \%$ & $47,3 \%$ & $39,2 \%$ & $49,4 \%$ & $84,6 \%$ & $20 \%$ & $40,8 \%$ & $29,8 \%$ \\
\hline & Estativo & $26,7 \%$ & $27,6 \%$ & $13,4 \%$ & $19,3 \%$ & $15,4 \%$ & $60 \%$ & $11,2 \%$ & $17,5 \%$ \\
\hline & Cognição & $9,5 \%$ & $18,2 \%$ & $41,9 \%$ & $24 \%$ & - & $20 \%$ & $47,2 \%$ & $52,6 \%$ \\
\hline & $\begin{array}{l}\text { Desloca- } \\
\text { mento }\end{array}$ & $6 \%$ & $7 \%$ & $5,4 \%$ & $7,3 \%$ & - & - & $0,8 \%$ & 0 \\
\hline $\begin{array}{l}\text { Material } \\
\text { interveniente } \\
(\text { dados/\%) }\end{array}$ & [Presença] & $5 / 4,3 \%$ & $31 / 11,3 \%$ & $63 / 13,2 \%$ & $66 / 18,4 \%$ & $\begin{array}{c}1 / \\
7,14 \%\end{array}$ & $1 / 16,6 \%$ & $34 / 27,2 \%$ & $18 / 31,6 \%$ \\
\hline $\begin{array}{l}\text { Natureza do } \\
\text { material }\end{array}$ & Tipo & $\begin{array}{c}\text { OBJ } \\
(1 / 20 \%), \\
\text { PRON } \\
\text { REFL } \\
(4 / 80 \%)\end{array}$ & $\begin{array}{c}\text { SADV, } \\
\text { PRON } \\
\text { REFL } \\
(13 / 42 \%), \\
\text { LOC } \\
\text { CONJ, } \\
\text { OBJ OBL } \\
\text { (7/ 22,6\%), } \\
\text { SUJ + OBJ }\end{array}$ & $\begin{array}{c}\text { SADJ, } \\
\text { SADV/ } \\
\text { SPREP L, } \\
\text { SADV/ } \\
\text { SPREP T, } \\
\text { SADV/ } \\
\text { SPREP M, } \\
\text { SADV AF, } \\
\text { IIS, } \\
\text { OBJ OBL } \\
\text { (14/22\%), } \\
\text { PRON } \\
\text { REFL } \\
\text { (8/14\%), } \\
\text { SUJ/ SUJ } \\
\text { PRON } \\
\text { (4/20\%) }\end{array}$ & $\begin{array}{c}\text { ADJ, } \\
\text { SADV/ } \\
\text { SPREP L, } \\
\text { SADV/ } \\
\text { SPREP T, } \\
\text { SADV M, } \\
\text { IIS } \\
(8 / 12 \%), \\
\text { OBJ OBL } \\
(23 / 35 \%), \\
\text { PRON } \\
\text { REFL } \\
(13 / 20 \%), \\
\text { SUJ/ SUJ } \\
\text { PRON } \\
(8 / 12 \%)\end{array}$ & $\begin{array}{l}\text { SPREP L } \\
\text { (1) }\end{array}$ & SPREP M (1) & $\begin{array}{c}\text { ADJ } \\
(6 / 17,6 \%), \\
\text { SADV/ } \\
\text { SPREP L } \\
(8 / 23,5 \%), \\
\text { SADV/ } \\
\text { SPREP T } \\
(6 / 17,6 \%), \\
\text { SADV/ } \\
\text { SPREP M } \\
(7 / 20,6 \%), \\
\text { SADV } \\
\text { NEG, } \\
\text { OBJ } \\
\text { OBL, SUJ } \\
(5 / 14,7 \%)\end{array}$ & $\begin{array}{c}\text { ADJ, } \\
\text { SADV/ } \\
\text { SPREP L } \\
(8 / 44,4 \%) \text {, } \\
\text { SADV/ } \\
\text { SPREP T } \\
\text { (7/39\%), }\end{array}$ \\
\hline \multicolumn{2}{|c|}{ Total de dados: } & 116 & 275 & 479 & 358 & 14 & 5 & 125 & 57 \\
\hline
\end{tabular}

Quadro 5. Comparativo das construçóes perifrásticas de gerúndio no português brasileiro e no galego $^{15}$ (adaptado de Oliveira 2018: 230).

No que tange à grande ocorrência de clíticos intercalando os itens da construção no galego, ela parece ser explicada por um traço característico dessa língua, já apontado por diversos estudos, que é a adoção da ênclise como posição canônica dos clíticos

15. SPREP- Sintagma preposicional; OBJ- objeto; PRON REFL- pronome reflexivo; SADV- sintagma adverbial; LOC CONJ- locução conjuntiva; M- modo; T- tempo; L- lugar; IIS- índice de indeterminação do sujeito; SUJ- sujeito; SADVNEG- sintagma adverbial de negação; SADVAF- sintagma adverbial de afirmação; OBL-oblíquos; ADJ-adjetivo; PRON-pronome. 
em relação ao verbo na maioria das construçóes dessa língua, exceto os casos especiais, restritos a contextos muito específicos (Lopes Castro 2006: 93). Em contextos perifrásticos, estudos na área também apontam esta preferência do idioma: "Nas perífrases verbais co verbo auxiliar en xerundio o pronome vai enclítico a este ou no lugar que lle corresponder co verbo auxiliar: Estouno observando / Estou observándoo". (Freixeiro Mato 2006: 174). O mesmo se observa em Álvarez (1996):

Nas oracións de infinitivo e xerundio a posición normal é a énclise. Obsérvase isto tamén, como proceso a punto de concluír ou como tendéncia moi marcada, en contextos en que a lingua antiga optaba pola próclise. [...] O único esquema en que segue sendo lixeiramente maioritaria a próclise, aínda que non cos niveis antigos, é aquel en que se combinan a presencia dunha preposición e o carácter negativo do predicado: por non lle dicir nada. (Álvarez 1996: 33)

Apesar de a ênclise ser também a posição recomendada pelas gramáticas da língua portuguesa, ela é rara no PB, sobretudo na fala espontânea. No galego, por outro lado, esses usos são correntes e naturais aos falantes, inclusive em situaçôes menos monitoradas de fala (Lopes Castro 2006: 92).

Para Freixeiro Mato (2006), este traço que afasta o galego do português pode ser explicado pela influência do castelhano sobre aquela língua:

Certo é que o galego na maior parte das ocorrencias permite a dupla posibilidade, próclise e énclise, e así se rexistra tanto na lingua oral como na escrita. Mais tamén é certo que a tendencia xeral cara á simplificación da opcionalidade arredor da énclise vén supor, máis unha vez, a confluencia coa solución castelá e o afastamento da tradición lingüística galego-portuguesa e da práctica dominante no portugués actual. (Freixeiro Mato 2006: 174-175)

Por fim, vale destacar outra singularidade da língua galega, atestada apenas em dois dados da amostra, particularmente em relação à construção [estar + X-ndo] cursivo, que se refere ao preenchimento do V2 pelo mesmo verbo do V1 [estar + estando $]_{\text {cursivo }}$, como mostram os exemplos a seguir, casos náo atestados para o PB no estudo realizado.

(33) O tío Vladimiro si, porque é especial, alguén que está aí sen estar e non está estando, híbrido de persoa e móbel, mais non podo seguir narrando igual. (Relato curto / 2006- CORGA- Séc. XXI)

(34) Sen ir máis lonxe, hai unhas semanas resistían os golpes das ondas como podían e dedicábanse a tirarse os dossiers á cabeza sen recato ningún. Non é explicável como o fai o líder da dereita española. Parece que non está es- 
tando, a resultas de que nunca estibo. Esta sería a frase que indicaría o xeito de facer política e sobrevivir de Mariano Rajoy. (Jornal/ 2009- CORGASéc. XXI)

Empregos como este podem configurar nesta língua, ainda, construçóes cristalizadas com valores bem específicos, o que precisa ser apurado com mais atenção em um estudo que trate com detalhes do emprego desses casos entre os seus falantes.

\section{Consideraçóes finais}

Este trabalho mostrou que o quadro geral do fenômeno é similar nas duas línguas analisadas, apesar das particularidades identificadas em cada idioma. Sinalizou também que o galego apresenta resultado semelhante ao encontrado para o PB: o de que $[e s t a r+\mathrm{X}-n d o]_{\text {cursivo }}$ tem um uso mais amplo, em termos de frequência type, no período contemporâneo, enquanto $[\text { iccar }+\mathrm{X}-n d o]_{\text {cursivo }}$ apresenta mais restriçóes combinatórias. Tais construçóes também parecem se complementar distribucionalmente, nesses dois idiomas, quanto a certos fatores, a exemplo do tempo verbal, do tipo semântico ou do emprego do sujeito.

Em termos de esquematicidade, produtividade e composicionalidade, o avanço da construção [estar $+\mathrm{X}-n d o]_{\text {cursivo }}$ foi evidenciado pela possibilidade de novos preenchimentos dos slots por verbos modais ou apassivadores, conservando a leitura perifrástica cursiva da construçáo, e ampliando, consequentemente, seu contexto de uso. Tal produtividade também pode ser apontada pela sua maior frequência de ocorrência $\left(\right.$ token), e pela menor restriçáo de uso comparada à construçáo $[\text { icar }+\mathrm{X}-n d o]_{\text {cursivo }}$. Esta, como mostrado em (23) e (24), apresenta certo enfraquecimento da leitura perifrástica cursiva em determinados contextos, o que pode indicar uma menor integração/consolidação da perífrase.

Além disso, $[\text { estar }+\mathrm{X}-n d o]_{\text {cursivo }}$ se mostrou menos composicional, tendo em conta a manutenção da leitura conjunta em diferentes situaçôes e a menor possibilidade de interrupção dos elementos da perífrase ou a ocorrência de elementos que não prejudicassem sua leitura construcional, náo somatória, como discutido anteriormente e exemplificado com os dados percentuais. Já em termos de esquematicidade, a modalização observada com esta construção pode deixar indícios de captação de novas construçôes na língua, o que precisa ser avaliado com mais detalhes numa amostra maior.

No entanto, a análise sugere que, apesar dessa similaridade nessas línguas, o processo da mudança com [estar $+\mathrm{X}-n d o]_{\text {cursivo }}$ parece estar ainda mais avançado no PB, pelo aumento de produtividade (ampliação do tipo e natureza do sujeito, e alta e diversificada modalidalização), de esquematicidade (recrutamento de novas construçóes, como as de gerundismo) e pela redução de composicionalidade (baixa fre- 
quência de material interveniente e presença de poucos materiais que enfraqueçam sua leitura perifrástica).

É importante reforçar, por fim, que este estudo não esgota as discussôes em torno do tema, apenas aponta resultados gerais da comparação entre o português e o galego no que se refere ao emprego de construçóes perifrásticas de gerúndio de aspecto cursivo e, ao apresentar esse quadro, permite identificar aproximaçóes e particularidades dessas duas línguas que guardam entre si estreito grau de parentesco. Ademais, uma análise mais geral, que não se debruça sobre informaçóes e detalhamentos estatísticos, como se propôs aqui, acaba por ocultar também o grau exato de aproximação e distanciamento entre essas duas línguas dentro do recorte analítico procedido, o que abre espaço para mais investigaçôes dentro desta temática.

A expectativa de trabalhos como este é a de fomentar novos estudos comparativos entre essas duas línguas por meio de análises de fenômenos de diferentes níveis da gramática, uma vez que este estudo procurou evidenciar que fenômenos atestados em uma língua podem ajudar a elucidar a análise na outra e a identificar padróes próprios do galego-português. Resta, portanto, o convite para aprofundamento deste tema e a realização de novas investigaçóes no âmbito interlinguístico.

\section{Agradecimentos}

Agradeço aos professores Dra. Maria Luiza Braga e Dr. Xulio Sousa Fernández, que me ajudaram mais diretamente nesta pesquisa. Também ao apoio institucional da Capes, pela concessão da bolsa de Doutorado sanduíche, do Programa de Pós-graduação em Linguística da Universidade Federal do Rio de janeiro, pela viabilização da pesquisa e da minha formação acadêmica, e ao Instituto de Língua Galega e à Universidade de Santiago de Compostela pelo acolhimento e suporte material e bibliográfico. Por fim, agradeço aos revisores deste texto pelas ricas contribuiçóes dadas ao trabalho, e à editora da revista pela condução das discussóes. 


\section{Referências bibliográficas}

Álvarez, Rosario. 1996. Posición do pronome átono en construcións de infinitivo e xerundio. Verba 23, 11-35.

Álvarez, Rosario \& Xose Xove. 2002 Gramática da lingua galega. Vigo: Editorial Galaxia.

Barroso, Henrique. 1994. O aspecto verbal perifrástico em português contemporâneo: visão funcional/ sincrônica. Porto: Porto editora.

Bybee, Joan L. 2003. Mechanisms of change in grammaticization: The role of frequency. Em B.D. Joseph \& J. Janda (eds.), The Handbook of Historical Linguistics. 602-623. Oxford: Blackwell.

Bybee, Joan. L. 2010. Language, usage and cognition. Cambridge: Cambridge University Press.

Castilho, Ataliba T. de. 1968. Introdução ao Estudo do Aspecto Verbal na Lingua Portuguesa. Marília, SP: Faculdade de Filosofia, Letras e Ciências Humanas.

Centro Ramón Piñeiro para a investigación en humanidades: Corpus de Referencia do Galego Actual (CORGA) [3.2] <http://corpus.cirp.gal/corga/> [Data da consulta: 30/04/21]

Coelho, Sueli. 2006. Estudo diacrônico do processo de expansão gramatical e lexical dos itens TER, HAVER, SER, ESTAR e IR na Lingua Portuguesa. Belo Horizonte: Faculdade de Letras/ UFMG. [Tese de Doutorado]

Freixeiro Mato, Xosé R. 2002. Sobre as perífrases verbais en galego (do século XIX à actualidade). Em Isabel Margarida Duarte, Joaquim Barbosa, Sérgio Matos \& Thomas Hüsgen (orgs.), Actas do Encontro comemorativo dos 25 anos do Centro de Linguística da Universidade do Porto. 269286. Porto, Universidade do Porto, Centro de Linguística. <http://ler.letras.up.pt/uploads/ficheiros/7184.pdf> [Consulta: 20/05/2021].

Freixeiro Mato, Xosé R. 2006. Gramática da língua galega II-morfosintaxe. 2a ed. Vigo: A Nosa Terra.

Gonçalves, Anabela. 1996. Aspectos da sintaxe dos verbos auxiliares do português europeu. Em Anabela Gonçalves, Madalena Colaço, Matilde Miguel \& Telmo Móia, (eds.), Quatro Estudos em Sintaxe do Português. 7-51. Lisboa: Colibri.

Halliday, Michael A. K. \& Christian Matthiessen. 2004. An Introduction to Functional Grammar. $3^{\text {rd }}$ edition. London: Edward Arnold.

Heine, Bernd. 1993. Auxiliaries. Cognitive Forces and Grammaticalization. New York Oxford University Press.

Himmelmann, Nikolaus P. 2004. Lexicalization and grammaticization: Opposite or orthogonal? Em Walter Bisang, Nikolaus P. Himmelmann, N. \& W. Björn (eds.), What Makes Grammaticalization - A Look from its Fringes and its Components. 21- 42. Berlin: Mouton de Gruyter.

Lehmann, Christian (2008). A auxiliarização de 'ficar'. Linhas gerais. En Maria Clotilde Almeida, Bernd Sieberg \& Ana Maria Bernardo (eds), Questions on language change. 9-26. Lisboa: Colibri.

Lobato, Lucia M. 1975. Os verbos auxiliares em português contemporâneo: critérios de auxiliaridade Em Lucia Lobato, Bernard Pottier, Francisco D’Introno, Anne-Marie Loffler-Laurian \& Anne-Marie Vidal (eds.), Análises linguísticas. 27-91. Petrópolis: Editora Vozes.

Longo, Beatriz N. 1990. A auxiliaridade e a expressão do tempo em Português. Araraquara: Faculdade de Ciências e Letras da Universidade estadual Paulista. [Tese de Doutorado em linguística]. 
Lôpes Castro, Maurício. 2006. Manual de iniciaçom à língua galega sociolinguistica, morfossintaxe, ortografia e léxico. Ferrol, Galiza: Fundaçom Artábria.

Maurer JR, Theodoro H. 1968. O infinitivo flexionado português. São Paulo: Cia Editora Nacional-USP.

Olbertz, Hella. 1998. Verbal periphrases in functional grammar of Spanish. Berlin / New York: Mouton de Gruyter.

Oliveira, Quezia dos S. L. 2018. Construcionalização e mudanças construcionais das perífrases cursivas de gerúndio no português. Rio de Janeiro: Faculdade de Letras/ UFRJ. [Tese de Doutorado].

Osório, Paulo \& Ignacio Vázquez Diéguez. 2018. Dados diacrónicos da estrutura durativa em português e em galego. Estudos de Linguistica Galega 10, 87-101. https://doi.org/10.15304/elg.10.5013

Palmer, Frank R. 1979. Modality and the English Modals., London and New York, USA: Longman.

Palmer, Frank. R. 1986. Mood and Modality. Cambridge University Press, New York, USA.

Partee, Barbara. 1984. Compositionality. Em Fred Landman and Frank Veltman (eds.), Varieties of Formal Semantics. 281-312. Dordrecht: Foris.

Possenti, Sírio. 2005. Defendendo o gerúndio. Discutindo língua portuguesa Ano 1, no 1, 8-11.

Rojo, Guillermo. 1974. Perifrasis verbales en el gallego actual. Verba, Anuario gallego de filologia, Anejo 2- Vigo: Universidade de Santiago de Compostela.

Santamarina, Antón (dir.)/ Ernesto González Seoane \& María Álvarez de la Granja: Tesouro informatizado da lingua galega (Versión 4.1). Santiago de Compostela: Instituto da Lingua Galega. $<$ http://ilg.usc.gal/TILG/> [Consultado: 30/04/21]

Serrone, Luiz Carlos. 1992. Critérios de auxiliaridade em português. Curitiba: Universidade Federal do Paraná. [Dissertação de Mestrado].

Sigiliano, Natalia S. 2013. A construção aspectual inceptiva do português com verbos não canônicos. Rio de Janeiro: Faculdade de Letras/ UFRJ. [Tese de doutorado]

Tavares, Maria Alice. 2018. Graus de integraçáo entre os verbos da perífrase V1 (E) V2 em uma perspectiva de interface variaçấo-gramaticalização. Entrepalavras 8-2, 381-400.

Torres, Fábio Fernandes. 2009. O gerúndio na expressäo de tempo futuro: um estudo sociofuncionalista. Fortaleza-CE: Universidade Federal do Ceará. [Dissertaçâo de Mestrado]

Traugott, Elizabeth. C. \& Graeme Trousdale. 2013. Constructionalization and Constructional Changes. Oxford, Oxford University Press.

Travaglia, Luiz Carlos. 2007. A gramaticalização dos verbos passar e deixar. Revista da Abralin 6-1, $1-31$.

Travaglia, Luiz Carlos. 2015. Aspecto verbal: a categoria e sua expressão (5a ed.). Uberlândia, MG: EDUFU.

Vieira, Márcia dos S. M. 2004 Perífrases verbais: o tratamento da auxiliaridade. Em Vieira, Silvia R.; Brandão, Silvia F. (org.) Morfossintaxe e ensino do português: reflexōes e propostas. 65-96. Rio de Janeiro, Faculdade de Letras, UFRJ.

Volpato, Arceloni. \& Iris S. Pires Pereira. 1997. A construção progressiva em Português: considerações histórico-semânticas. Em Ivo Castro (ed.), Actas do XII Encontro Nacional da Associação Portuguesa de Linguística. Vol. 2. 341-346. Lisboa: Associação Portuguesa de Linguística. 